\title{
Наследие долгожителя-геронтолога Захара Френкеля в фондах Музея истории медицины им. П. Страдыня
}

Одной из ярчайших фигур в российской медицине является Захар Григорьевич Френкель (1869-1970) - видный общественный деятель, земский врач, заслуженный деятель науки РСФСР, академик АМН СССР (с сентября 1945 г.), гигиенист, демограф, геронтолог.

По окончании (в 1895 г.) Тартуского (Дерптского) университета (медицинского факультета) Френкель поступил на службу в СанктПетербургское губернское земство. За исключением нескольких административных высылок (Вологда, Кострома, Ярославль) почти 75 лет из 100 лет жизни Френкеля связано с городом на Неве. Всю свою профессиональную деятельность он посвятил борьбе за улучшение условий жизни населения России. Он писал об этом в отчетах, журнальных статьях, земских изданиях. «Скромный санитарный врач-энтузиаст 3. Г. Френкель завоевал огромный авторитет своей эрудицией, бескомпромиссностью, беззаветным и самоотверженным трудом, стал своего рода знаменем общественной медицины». ${ }^{1}$

Депутат Первой государственной думы (1906), главный редактор журнала «Земское дело» (1912-1914), депутат Центральной городской (Петроградской) думы (1917) от партии народной свободы (кадеты) Френкель занимался социально-экономическими и правовыми

${ }^{1}$ Белицкая Е. Я. Научные гигиенические школы Ленинграда. - Ленинград, 1982. - C. 118-130. 
аспектами медицинских проблем для отдельных половозрастных и профессиональных групп населения, повышением их образованности. Всё это решалось Френкелем на основе его исключительного опыта успешной работы в земских учреждениях, с одной стороны, и долгой работы в Северном союзе городов (участие в проектировании крупных городов в период их формирования на территории России, их водоснабжения, канализации, благоустройства). Такое сочетание позволило ему реализовать важные социальные проекты и в дореволюционной, и в послереволюционной России; стать автором монографических исследований (более 20). 3. Г. Френкель остается одним из крупнейших общественных деятелей, работы которого известны не только на территории бывшего СССР, но и за рубежом. Сразу после революции (1919) ученый основал кафедры коммунальной, социальной гигиены в медицинских институтах (и с преддипломной, и последипломной подготовкой); отдел коммунальной и социальной гигиены в Музее истории города (Ленинград, 1918-1932); отдел гигиены в Институте экспериментальной медицины (ИЭМ, 1932-1934); отдел социальной патологии в НИИ туберкулеза (Ленинград). Активно, в течение многих лет, трудился Френкель на посту руководителя Ленинградского отделения Всероссийского гигиенического общества, не прекращавшего своих заседаний даже во время войны и блокады.

Но особенно значителен, более того - уникален, вклад Захара Григорьевича в развитие геронтологии как науки. И не только потому, что в 1957 г. он организовал одно из первых на территории бывшего СССР, одно из немногих в России Ленинградское научное общество геронтологии и гериатрии. Он осуществил на практике давнюю мечту человечества: жить не менее 100 лет. Именно столько прожил сам Френкель.

Уникальную биографию ученого оценили не только в России, но и в Европе. Крупный польский демограф Эдвард Россет (Польша, 1897-1989) 7 января 1970 г. в письме Френкелю заметил:

«Немало людей занималось вопросом долголетия», однако известны «лишь два примера личного осуществления тезиса о реальности продления человеческой жизни до ста лет. Первый 
пример - это итальянец Cornaro, автор изданного, пожалуй, в XV столетии труда о долголетии; второй пример дали Вы, глубокоуважаемый Захар Григорьевич». ${ }^{2}$

Но можно ли сознательно стать долгожителем или это благо, которое дается исключительно свыше?

Френкель был твердо убежден, что главным стимулом долголетия являются самообслуживание в повседневной жизни, постоянная тяга к совершенствованию, ежедневная тренировка речевой функции, систематическая занятость привычным трудом. Это положение Захар Григорьевич сформулировал в ответном слове на своем 100-летнем юбилее. Теперь уже современная геронтология доказала, что занятый человек, тем более творческая личность интактна старению. ${ }^{3}$

Хотя в то же время нельзя не отметить, что еще цари династии Романовых, заботясь о сохранении и приумножении российского народа, о судьбах инвалидов, всегда специально оговаривали вопросы занятости и трудоустройства. Этой проблеме были посвящены сотни указов против тунеядства. 4

Но переломным для науки о продлении человеческой жизни стал 1932 г. ${ }^{5}$ Тогда Френкель откликнулся на «социальный заказ». В 1934 г. на заседании Ученого совета ВИЭМ в Ленинграде Френкель выступил с докладом «К постановке в СССР проблемы удлинения жизни». В этой первой своей работе по геронтологии Захар Григорьевич заявил, что грандиозность задачи требует и государственного ее решения. Речь шла о формировании благоприятной социальной среды в рамках всего государства, которая создаст для

${ }^{2}$ В фондах РНБ 8 работ Луиджи Корнаро на русском языке. В них же есть информация об этом знатном венецианце. Кроме того, см. о нем: Шабров А. В., Князькин И. В., Марьянович А. Т. Илья Ильич Мечников / Энциклопедия жизни и творчества. - СПб., 2008. - С. 1131-1132.

3 Рудкевич Л. А. Возрастная динамика творческой продуктивности: Автореферат диссертации на соискание ученой степени кандидата психологических наук. - Спб., 1994. - 16 с.

4 См., в частности: Забозлаева Т. Б. Внутренняя политика императрицы Елизаветы Петровны (1741-1761). Путеводитель по законодательству. СПб., 2012. Глава «Медики и медицина».

5 Бахтияров Р. Ш. Социальный заказ на удлинение жизни: к истории проблемы // И. П. Павлов: достоверность и полнота биографии. - СПб., 2005. - C. 299 - 309 // http://www.medline.ru/public/Rashid_2004.pdf 
широких слоев населения предпосылки к здоровой и достойной, долгой и деятельной жизни. Уже в середине 1990-х гг. на основе идей 3. Г. Френкеля мною была предложена периодизация развития геронтологии, ее медико-социальных аспектов. ${ }^{6}$ поступил от самого И. В. Сталина в адрес Л. Н. Федорова, директора ВИЭМ.

С тех пора эта проблема никак не устарела, наоборот, стала еще более актуальной. Ибо, как заметила социолог В. Семенова, «никогда ранее старшее поколение не жило так долго. Никогда ранее в истории, не рождалось так мало потомков, которые могли бы их содержать». ${ }^{7}$

Между тем за последние 20 лет в связи с распадом СССР наметился все более увеличивающийся разрыв между практикой геронтологии (циклы работ члена-корреспондента РАН В. Н. Анисимова, члена-корреспондента РАМН, Президента Европейского отделения МАГГ В. Х. Хавинсона) и теоретическим осмыслением славного пути, который прошла наука от своих истоков до наших дней. А без достойного осмысления пройденного самая успешная практика может замедлить ход своего развития и зайти в тупик. Ведь никто не отменял основной закон диалектики: от прошлого в настоящее и будущее. В этой связи нельзя переоценить значение и опыт Музея истории медицины им. Паула Страдыня (Рига, Латвия).

Первое по времени возникновения в СССР учреждение такого рода является подлинным хранителем и памятью нашей медицинской науки. С 3 по 9 июня 2012 г. в Музее Страдыня прошел международный семинар «От экспоната до выставки». Интерес российских историков медицины, основных участников семинара, оказался велик потому, что в России пока не удалось создать профессиональный, стабильно функционирующий музей национального уровня. Особняк на улице Антонияс 1 в Риге, построенный в 1879 г., стал в 1957 г. местом расположения Музея, когда Страдынь передал государству свою частную коллекцию, которую он начал собирать ещё в 1920-1930-е гг. После смерти основателя в 1958 г. музею было присвоено его имя. Для широкой публики музей открыл свои двери в 1961 г.

6 Бахтияров Р. Ш. Социально-демографическая оценка старения населения крупного города (на примере Санкт-Петербурга). - Автореферат диссертации кандидата медицинских наук - СПб., 1996. - 18 с.

7 Семенова В. В. Социальная динамика поколений проблема и реальность. Москва: Институт социологии РАН, 2009. - С. 54. 


\section{Общая характеристика периодов развития геронтологии \\ в России (СССР), ее медико-социальных аспектов}

\begin{tabular}{|c|c|}
\hline $\begin{array}{c}\text { Название } \\
\text { периода, годы }\end{array}$ & $\begin{array}{c}\text { Наиболее важные } \\
\text { мероприятия периода }\end{array}$ \\
\hline $\begin{array}{c}\text { Предпосылки } \\
\text { (1880-1927) }\end{array}$ & $\begin{array}{l}\text { Получение и обработка статистических дан- } \\
\text { ных о состоянии здоровья, заболеваемости и } \\
\text { смертности населения с учетом возраста; накоп- } \\
\text { ление знаний и опыта в области диагностики, } \\
\text { лечения и профилактики возрастной патологии }\end{array}$ \\
\hline $\begin{array}{c}\text { Возникновение } \\
\text { (1927-1957) }\end{array}$ & $\begin{array}{l}\text { Обоснование необходимости изучения процес- } \\
\text { сов старения населения и создании соответ- } \\
\text { ствующих условий в жизни общества. Проведе- } \\
\text { ние первых экспедиций, конференций, научные } \\
\text { публикации }\end{array}$ \\
\hline $\begin{array}{c}\text { Формирование } \\
\text { (1957-1977) }\end{array}$ & $\begin{array}{l}\text { Принятие управленческого решения о создании } \\
\text { сети региональных научных обществ геронто- } \\
\text { логии и гериатрии; НИИ геронтологии АМН } \\
\text { СССР; научных Советов АМН СССР и АН СССР; } \\
\text { сети гериатрических организационно-методичес- } \\
\text { ких кабинетов (цели, задачи, структура, поря- } \\
\text { док взаимодействия, объем оказания помощи, } \\
\text { способы контроля). Принятие решения о созд-- } \\
\text { нии медико-социальной службы для пожилых. } \\
\text { Создание в Ленинграде, Днепропетровске и др. } \\
\text { регионах центров кабинетов. Открытие кафедры } \\
\text { гериатрии в Ленинградском ГИДУВ }\end{array}$ \\
\hline $\begin{array}{c}\text { Развитие и } \\
\text { совершенствование } \\
(1977-1991)\end{array}$ & $\begin{array}{l}\text { Проведение первых конференций, Ш, IV и V } \\
\text { всесоюзных съездов геронтологов и гериатров; } \\
\text { научные публикации; попытка создания АСПОН }\end{array}$ \\
\hline $\begin{array}{l}\text { Переходный } \\
\text { (с 1991) }\end{array}$ & $\begin{array}{l}\text { Выпуск первого всесоюзного журнала «Проб- } \\
\text { лемы старения и долголетия». Дезинтеграция } \\
\text { всесоюзных структур. Обобщение отечествен- } \\
\text { ного (российского) опыта. Проведение всерос- } \\
\text { сийской учредительной конференции (Стрельна, } \\
\text { Санкт-Петербург, 1994). Первые шаги преддип- } \\
\text { ломной подготовки специалистов. Проведение } \\
\text { российских съездов геронтологов и гериатров } \\
\text { (1999; 2003). Издание «Словаря терминов по со- } \\
\text { циальнойгеронтологии» (Москва-Самара, 1999) }\end{array}$ \\
\hline
\end{tabular}


Не случайно в 1963 г. после своего 90-летия 3. Г. Френкель принял решение о передаче музею большей части архива, справедливо полагая, что здесь его документы останутся в целости и сохранности. Музей Страдыня входит в число крупнейших историко-медицинских музеев мира. Сегодня в его фондах находится более 250 единиц хранения из документов Захара Григорьевича Френкеля. Это огромная цифра! Ведь сами фонды музея насчитывают 200 тысяч единиц хранения. Музей истории медицины в Риге - единственный музей на постсоветском пространстве, в котором существует обширная и уникальная по содержанию коллекция, отражающая различные вехи в развитии медицины советского времени.

Считаю своим долгом геронтолога, историка российской геронтологии назвать имена сотрудников, благодаря которым началось и продолжается мое знакомство и затем сотрудничество с Рижским музеем: Вильгельм Канеп, Карл Арон, Мария Лебедькова, Герта Ханзен, Эвелина Давидсон, супруги Ксенофонтовы - Лилия и Николай, Аркадий Хазанов, Клара Сеглениеце, Арнис Виксна, Эвалд Кронитис, Юрис Салакс, Юрий Сурдеко, Рута Вайновская, Нина Драч. Благодаря их поддержке стала возможной моя первая публикация в сборнике трудов музея. ${ }^{8}$

А теперь остановлюсь на некоторых, наиболее значимых, на мой взгляд, экспонатах Музея, имеющих отношение к Френкелю.

Иду по хронологии документов:

1. 1906-1917 гг. Депутат Первой государственной думы России и земский врач Френкель обобщил свой опыт в брошюре «Партия народной свободы и местное самоуправление». Опубликованная в июне 1917 г. в Петрограде, она давно стала библиографической редкостью. Мне не удалось ее разыскать даже в Российской национальной библиотеке (РНБ). Много слышавший об этой работе я впервые взял ее в руки в Рижском музее. Переоценить значение данного экспоната для историка невозможно. Ибо сущность самого земства в истории России является тайной за семью печатями, с одной стороны,

8 Бахтияров Р. Ш., Лихницкая И. И. Академик 3. Г. Френкель: концепция удлинения жизни и деятельной старости // Acta medico-historica Rigensia. Vol. V (XXIV). - Rīga, 2000. - 75.-84. lpp. 
a с другой - это кладезь опыта и знаний и для нашего сегодня, и для нашего завтра. Ибо мы не перестаем грезить о самоуправлении в обществе. Насколько важна была эта тема для автора, говорит тот факт, что в 1919 и 1926 гг. он продолжал над ней работать. В 1999 г. опыт Френкеля был вновь востребован. Книга «Волостное самоуправление» опять была издана в Москве.

Многие инициативы в демографии и социальной геронтологии, которые осуществлялись в предвоенные и послевоенные годы, не могли быть реализованы без 3. Г. Френкеля и его идей. В эти годы Френкель был повсюду, иногда как вдохновитель, иногда как подсказчик, иногда как разработчик или деятельный участник той или иной инновации. В 1920-е гг. в городе на Неве разрабатывались системы учета рождаемости, смертности, миграции; совершенствовались система охраны материнства и младенчества, физической культуры среди широких масс населения, основы последней были заложены П. Ф. Лесгафтом. Создавались предпосылки социальнодемографической квалиметрии жизненного цикла человека, семьи. Два профессора Ленинградского педиатрического медицинского института, друзья и коллеги Френкеля, Сергей Новосельский (1872-1953) и Владимир Паевский (1893-1934) инициировали в том же 1932 г. создание Демографического института АН СССР. Ряд работ этого института в свое время был передан мною в Рижский музей. Неожиданное упразднение Демографического института явилось причиной внезапной смерти Паевского.

Весной 1942 г. было учреждено Бюро санитарной статистики Ленинградского городского отдела здравоохранения. Бессменными участниками еженедельных научных заседаний бюро с 1942 по 1948 гг. были 3. Г. Френкель и его старшая дочь 3. З. Шнитникова де Лагарп (1899-1983), ${ }^{9}$ С. А. Новосельский, Л. С. Каминский (1889-1962), Е. Э. Бен (1893-1965), Е. Я. Белицкая (1906-1983) и др. Материалы об этих ученых также представлены в фондах Музея.

9 Бахтияров Р. Ш. Концепция исследований по демографии блокадного Ленинграда в проекте 3. Г. Френкеля // Вопросы статистики, 2001; 11: 76-80; К 100-летию со дня рождения 3. 3. Шнитниковой-Лагарп: Влияние войны на санитарное состояние населения (Ленинград периода войны и блокады) // Вопросы статистики, 1999; 8: 80-85. 
2. В 1911 г. в Дрездене проходила Международная гигиеническая выставка, которая имела большой резонанс в Европе. Сотрудники Дрезденского музея гигиены до сих пор вспоминают, что за несколько месяцев работы выставку посетило более пять миллионов экскурсантов. Российский павильон, построенный в виде терема, привлек особое внимание. Френкель, увлеченно водивший экскурсии на основных европейских языках, стал чуть ли не национальным героем немцев, представляя земскую медицину России. Во всяком случае, его научный авторитет не померк в Германии до сих пор. До конца дней он наизусть декламировал «Фауста» Гете. В Музее Страдыня имеются уведомление о награждении Френкеля Почетным дипломом Выставки и черновик диплома. Сам диплом до сих пор не найден.

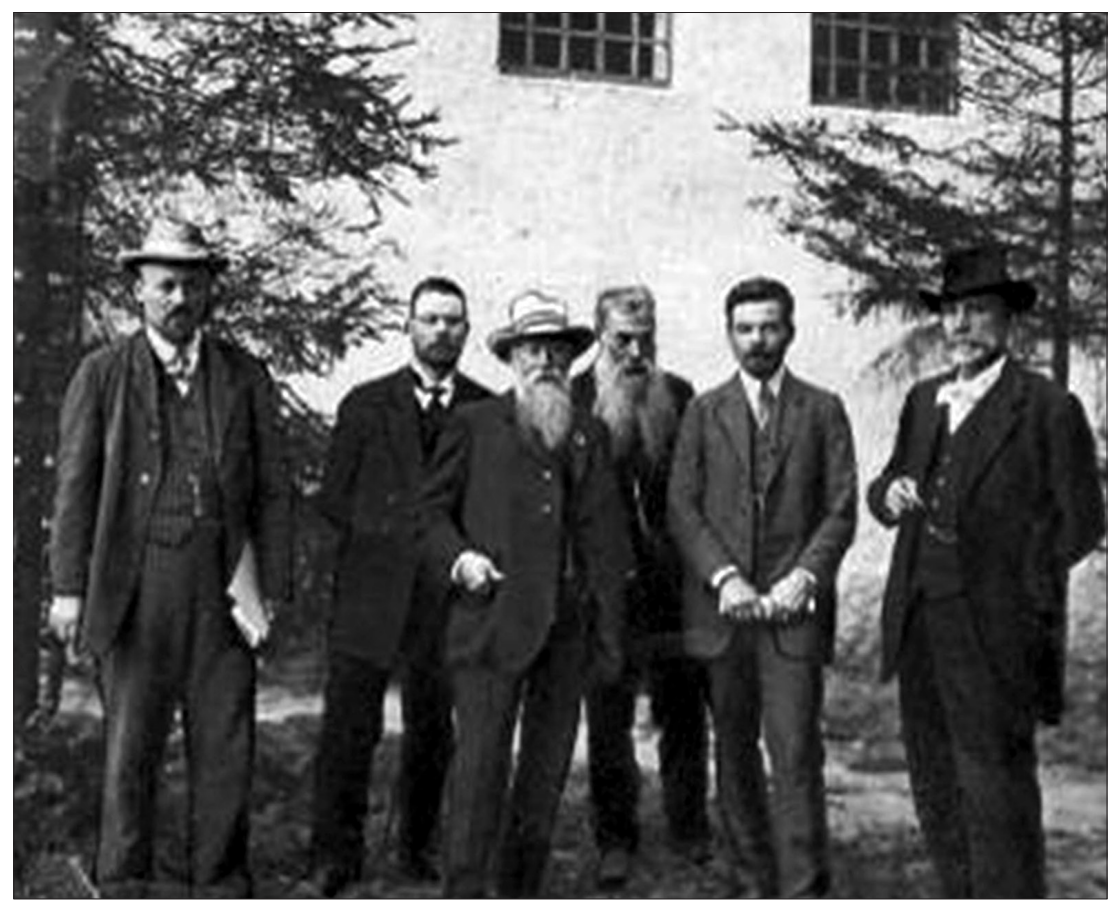

В Дрездене на Международной гигиенической выставке Захар Григорьевич Френкель (второй справа) встречался со знаменитым Ф. Ф. Эрисманом (в центре) 
На выставке Захар Григорьевич встречался со знаменитым Ф. Ф. Эрисманом.

3. Среди документов Рижского музея большую ценность представляют письма корреспондентов Френкеля (среди них видные ученые, ближайшие родственники ученого и др.). Особо выделю письма к 3. Г. Френкелю известного эпидемиолога (микробиолога) Льва Александровича Тарасевича (1868-1927), академика АН УССР. Их связывали общие научные интересы. Не случайно работая над документальной лентой о Тарасевиче (Академик Тарасевич, 1970), Эмиль Лотяну (тот самый, известный впоследствии кинорежиссер) в 1960 -е гг. приехал к Френкелю взять интервью для фильма.

4. 70 лет тому назад в марте 1942 г. из Куйбышева (теперь Самара) по радио прозвучала Седьмая (Ленинградская) симфония Дмитрия Шостаковича. Весна. В саду Френкеля распускаются листья растений, которым предстоит составить единственный букет на ленинградской премьере симфонии 9 августа 1942 г. ${ }^{10}$ В суровых условиях блокады Ленинграда ученый и педагог, преодолевая большие расстояния от дома в Лесном до учебных заведений на Пискаревке и у Таврического сада, продолжал работать над своим главным трудом «Удлинение жизни и активная старость». В победном 1945 г. книга вышла из печати. ${ }^{11}$ Экземпляр с автографом автора хранится в Музее Страдыня.

5. В 1959 г. научная общественность Советского Союза отмечала 90-летие Френкеля. В частности, от сотрудников Ленинградского санитарно-гигиенического медицинского института юбиляру был преподнесен памятный адрес в окладе из серебра. Поистине, царский подарок. И это тоже экспонат Музея Страдыня!

6. На выездной (один из немногих, но дважды единственный: по социальной геронтологии и персональный - памяти 3. Г. Френкеля) Пленум Правления Всесоюзного общества геронтологов и гериатров Лилия Ксенофонтова и Эвалдс Кронитис в июне 1990 г. привозили документы Френкеля из фондов Музея им. Страдыня. У меня хранится копия их тематико-экспозиционного плана. Мною (тогда еще

10 Бахтияров Р. Ш. Войдем же в этот сад! К истории единственного букета на премьере «Седьмой» // Линд Е. А. «Седьмая...». - СПб., 2005. - С. 172-176.

11 Бахтияров Р. Ш. Книга о здоровой и достойной, долгой и деятельной жизни 3. Г. Френкеля // Психология зрелости и старения, 2006; 4 (36): 85-129. 
безо всякого плана, но по интуитивным следам моих авторских выставок в Российской национальной библиотеке, 1984-2004) была устроена содержательная выставка в Клубе Военно-медицинской академии (ВМедА) в дни работы Пленума.

Bce перечисленные экспонаты (а также многие другие) натолкнули меня на мысль о создании виртуального Музея Захара Френкеля. Ибо я располагаю тоже многими памятными документами, отражающими жизнь и деятельность выдающегося ученого. Например, у меня есть аудиозапись 100-летнего юбилея Френкеля. Все эти документы и материалы зарегистрированы в декабре 1993 г. Архивным комитетом Санкт-Петербурга как частная архивная коллекция. В 2006 г. мною издан биобиблиографический указатель работ ученицы Френкеля И. И. Лихницкой (1908-2006). Сейчас я работаю над составлением аналогичного биобиблиографического указателя 3. Г. Френкеля. В связи с этим предлагаю Музею Страдыня объединить наши усилия по созданию (вначале виртуального) научного центра «Уроки российского долголетия». Составными частями этого центра видятся: библиотека, архив, музей. Для этого у меня многое уже есть. В частности, специализированная библиотека по геронтологии, демографии, истории медицины - 5000 единиц хранения. Список книг по истории медицины может быть уже сейчас выставлен на сайте Музея Страдыня. Обладая колоссальными ресурсами и объединившись, мы можем сообща создать действительно международный центр «Уроки европейского долголетия». Тем более, что в прошлом человечества было немало долгожителей, причем не только среди закавказских старцев, но и среди крупнейших общественных деятелей, политиков, поэтов.

Согласно предложенной периодизации становления геронтологии в России продолжаю исследовать период «предпосылки, 1880-1927 гг.». Совместно с Т. Б. Забозлаевой в настоящее время работаю над фундаментальным трудом «Государственная программа сохранения и приумножения народонаселения в Российской империи». Это развернутый путеводитель по полному собранию законов Российской империи, с 1649 г. до 1913 г. Знакомство с данным материалом будет большой неожиданностью для исследователей. Поскольку наши монархи придавали огромное значение «сбережению российского народа». 


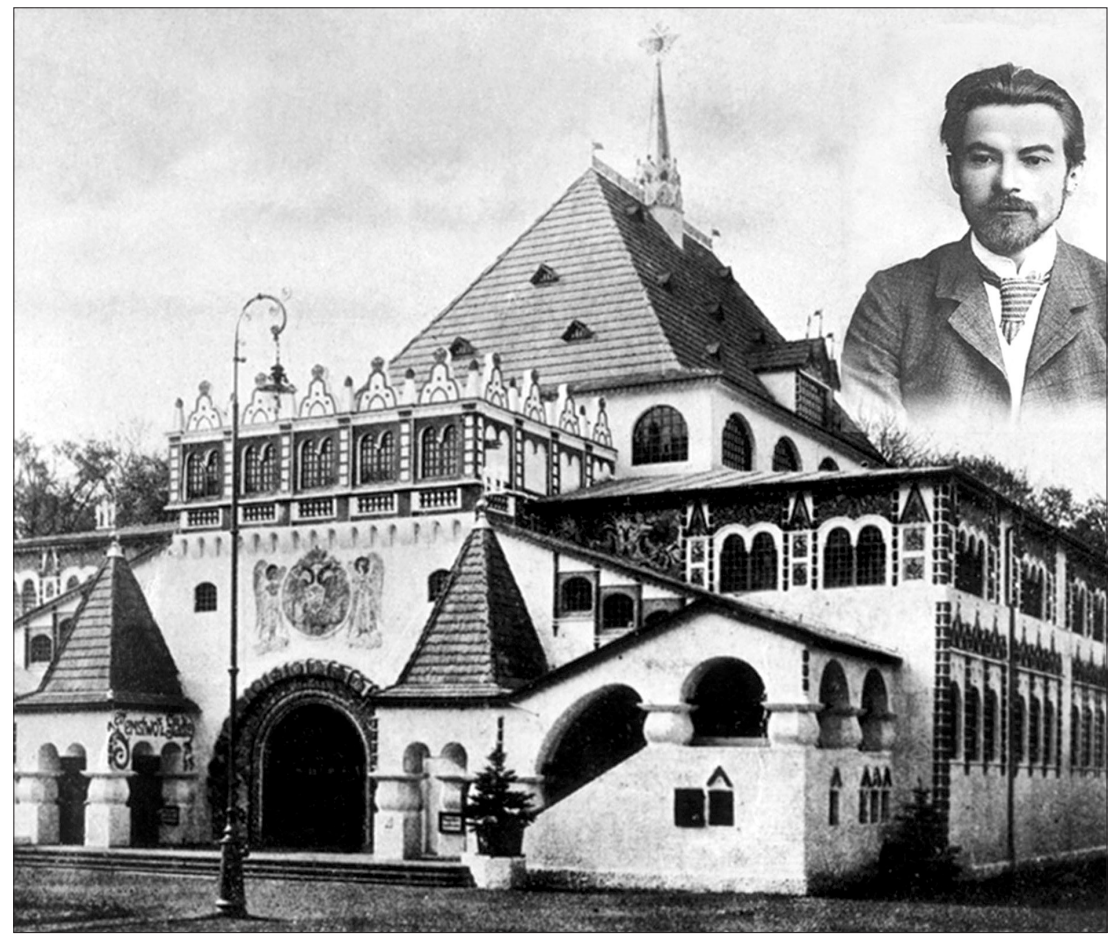

Российский павильон на Международной гигиенической выставке

в Дрездене построенный в виде терема, 1911 г.

Захар Григорьевич Френкель увлеченно водил экскурсии посетителям павильона. Вверху - сам 3. Г. Френкель (коллаж)

Подытоживая свои заметки, хочу еще раз напомнить о долге нашего профессионального (историки медицины, музейщики, архивисты, библиотекари) сообщества. Наша задача не потерять, не забыть опыт выдающихся предшественников, но сделать его достоянием как можно большего числа людей.

К 140-летию 3. Г. Френкеля вышли:

1) его «Воспоминания о пройденном жизненном пути» (СПб., 2009, 696 c.);

2) монография А. П. Щербо «Жизнь длиною в век» (СПб., 2009, 584 c.). 
Выставка в Библиотеке РАН (http://www.rasl.ru/content/news), конференция памяти ученого (Санкт-Петербургская медицинская академия последипломного образования, 18 декабря 2009 г.) и эти два издания оживили интерес к его незаурядной личности.

Давняя греза Захара Григорьевича Френкеля, геронтолога долгожителя, о здоровой и достойной, долгой и деятельной жизни должна стать явью уже сегодня.

\section{Ilgdzīvotāja gerontologa akadēmiķa Zahara Frenkel̦a mantojums Paula Stradiṇa Medicīnas vēstures muzeja fondos Latvijā}

\section{Kopsavilkums}

Zahars Frenkelis (1869-1970) ir viena no spilgtākajām personībām Krievijas medicīnā. Viņš bija pazīstams sabiedriskais darbinieks, zemstes ārsts, KPFSR Nopelniem bagātais darbinieks, PSRS Medicīnas akadēmijas akadēmiķis, higiēnists, demogrāfs un gerontologs.

1919. gadā viņš dibināja Komunālās un sociālās higiēnas katedru medicīnas institūtos, vēlāk izveidoja Komunālās un sociālās higiēnas nodaḷu vēstures muzejā L̦eņingradā, kā arī Sociālās patolog̣ijas nodaļu Tuberkulozes zinātniski pētnieciskajā institūtā.

Frenkelis visvairāk strādājis un devis gerontolog̣ijas attīstībai. Viṇa sapnis bija sasniegt cilvēka dz̄̄ves garumu - 100 gadus. Tieši tik nodzīvoja arī pats zinātnieks. Tā kā Padomju Savienībā nebija un Krievijā joprojām nav nacionāla līmeņa medicīnas muzeja, tad 1963. gadā Z. Frenkelis savu kolekciju nodeva P. Stradiņa Medicīnas vēstures muzejam, kur tā joprojām glabājas un ir pieejama zinātniskiem pētījumiem.

Autoram ir sapnis par Zahara Frenkeḷa virtuālā muzeja izveidi sadarbībā ar Paula Stradiṇa Medicīnas vēstures muzeju. 


\section{Legacy of Longevity-Gerontologist in \\ Collections of Riga Pauls Stradins Museum \\ of History of Medicine: Academician \\ Zahar Frenkel at the National \\ Museum of Latvia}

\section{Abstract}

One of the most prominent figures in Russian medicine is Zakhar Frenkel (1869-1970) - academician of the Academy of Medical Sciences (September 1945), a hygienist, a demographer, gerontologist. Frenkel is one of the major public figures whose works are known not only in the former USSR but also abroad. Immediately after the revolution (1919), the scientist founded the Department of Communal, Social Hygiene in medical schools (and undergraduate and postgraduate training) department and Municipal Social Hygiene at the Museum of the City (Leningrad, 1918-1932), Department of Hygiene in the IEM (1932-1934), Department of Social Pathology in Tuberculosis Research Institute (Leningrad). Active for many years, Frenkel worked as the head of the Leningrad Branch of the All-hygienic society, to continue their meetings, even during the war and blockade.

Yet, Frenkel has a particularly significant contribution to the development of gerontology as a science. And not just because in 1957 he organized one of the few Russian-parameter Leningrad Scientific Society of Gerontology and Geriatrics, ranking amongst the first in the former Soviet Union. He realized in practice, pressure old dream of mankind to live at least 100 years old, which is the age Frenkel lived up to himself. He was convinced that the main impetus of longevity are self-service in everyday life, a constant desire for improvement, daily exercise, training of speech function, systematic employment of the usual difficulty. This provision was formulated in his response to his 100 -year anniversary by Frenkel himself.

In 1963, after his $90^{\text {th }}$ birthday, Frenkel made the decision to transfer much of his Archives, believing that here his documents remain intact.

In the article (for example, several exhibits) legacy of the scientist is presented, carefully stored in Riga Pauls Stradins Museum of History 
of Medicine. It is proposed to establish (a basis for the European Center for Lessons longevity) the Virtual Museum of Frenkel. The long-standing dream of Zakhar Frenkel, gerontologist - longevity, a healthy and dignified, a long and active life - should become the reality today.

Рашид Шаазамович Бахтияров, к. м. н.

Санкт-Петербургский государственный педиатрический медицинский университет

rashid46spb@gmail.com 